\title{
PBL Teaching Method through Cooperative Learning
}

\author{
Eduardo Dopico (Corresponding author) \\ Department of Educational Science, University of Oviedo \\ C/ Aniceto Sela s/n. 33005-Oviedo, Spain \\ E-mail: dopicoeduardo@uniovi.es
}

Dolores Pevida

IES Pando

Avenida de Pando, 40, 33011 Oviedo, Asturias, Spain

Received: March 6, 2017

Accepted: March 16, 2017

Published: March 20, 2017

doi:10.5296/gjes.v3i1.10954

URL: https://doi.org/10.5296/gjes.v3i1.10954

\begin{abstract}
The challenges proposed by the knowledge society requires a change of mentality and routines of our students. Consequently, a shift is also needed in the role played by teachers in their education. 34 secondary school teachers from three Spanish high schools, from Ceuta, Madrid and Asturias, working as part of a network, began to introduce project-based learning (PBL) and cooperative learning to facilitate this change. We analyze the correlations between the beliefs and the attitudes of teachers when they were initiating a methodological transition in their patterns of teaching. At the same time, we compare the competencies and strategies related with PBL that 372 secondary school students from these high schools consider being personally important with those who they believe necessary to improve their learning or to be successful with academic requirements.
\end{abstract}

Keywords: Teacher role, Student role, Project-based learning, Cooperative learning, Teaching-learning methods 


\section{Introduction}

The knowledge society requires a change in the mentality and routines of our teachers and students: in teaching methods, in the quality of learning and in the competencies developed in classrooms (Clifford et al., 2004; Deslauriers et al., 2011; Kirby \& Lawson, 2012; European Commission, 2013). Social organization, the interests and motivations of students, teachers' training and the aims proposed by school, must place us on the way to innovation (Kärkkäinen, 2012), to the methodological progress to provide lifelong learning (Eurostat, 2014; Klug et al., 2014). These ideas gave rise to the formation of a group of secondary school teachers from the centers IES Maria Guerrero from Madrid, IES Clara Campoamor from Ceuta and IES Pando from Asturias, interested in promoting new methodological dynamics in teaching practices that could improve the academic achievement of their students (Trujillo, 2012). Their concerns were directed toward changing the roles that must be present in the classroom to meet the demands of our times. In a participatory action research strategy (Bergold \& Thomas, 2012), reflection in common highlighted urgent challenges that teachers were willing to face. Teachers should not remain the backbone of the knowledge presented in class. It was urgent to put aside the discursive teaching methods and promote new ways in the practice of teaching toward an active methodology that would support the teaching-learning process (Pevida \& Gallego, 2013; Canaleta et al., 2014). Thus, in January 2015 the three high schools involved in this study began to introduce simultaneously in their subjects the Project Based Learning (PBL) methodology, which advocates a change in teachers' roles: understanding competency-based learning to improve the relevance of what is learned and facilitate the integration of contents (Efstratia, 2014). Focusing on meaningful learning, which promotes the autonomy of learners and learning by doing (Teúileanu, 2014), they bet on cooperative learning as a strategy for educational action (Gillies \& Boyle, 2010), developing shared interactions among students and teachers in the classroom, positive interdependencies between participants, autonomy in learning, teaching-learning among peers and individual responsibility in the learning process (English \& Kitsantas, 2013).

As in any innovative initiative, there is resistance in some schools (Terhart, 2013), sometimes from teachers who are not comfortable in contexts that they think they do not control, making them feel unsafe and, occasionally, distrustful of the benefits of these active methodologies (Holmes et al., 2013). Other times it is the school organization itself that refuses to modify its routines: accustomed to very hierarchical structures, it is not flexible enough to confront proposals that transcend the walls of the center and require transversality between several subjects, and involve several professionals, including participants external to the school (Murphy et al., 2013). In any case, the working group created to promote and coordinate these educational actions began the task of designing projects and recruiting other teachers to use these methodological changes (Emo, 2015). Students were involved in brainstorming sessions for different projects with the teachers for each subject. We analyzed the correlations between the beliefs and the attitudes of teachers both professionally and personally when they were initiating a new methodological approach in their patterns of teaching. We also compared competencies and strategies related with PBL that students considered important in improving their knowledge or in meeting academic requirements. 


\section{MInstitute"}

\section{Material and Methods}

The study sample was composed of three Spanish secondary schools: IES Maria Guerrero (Madrid), IES Clara Campoamor (Ceuta), and IES Pando (Asturias) (Figure 1).

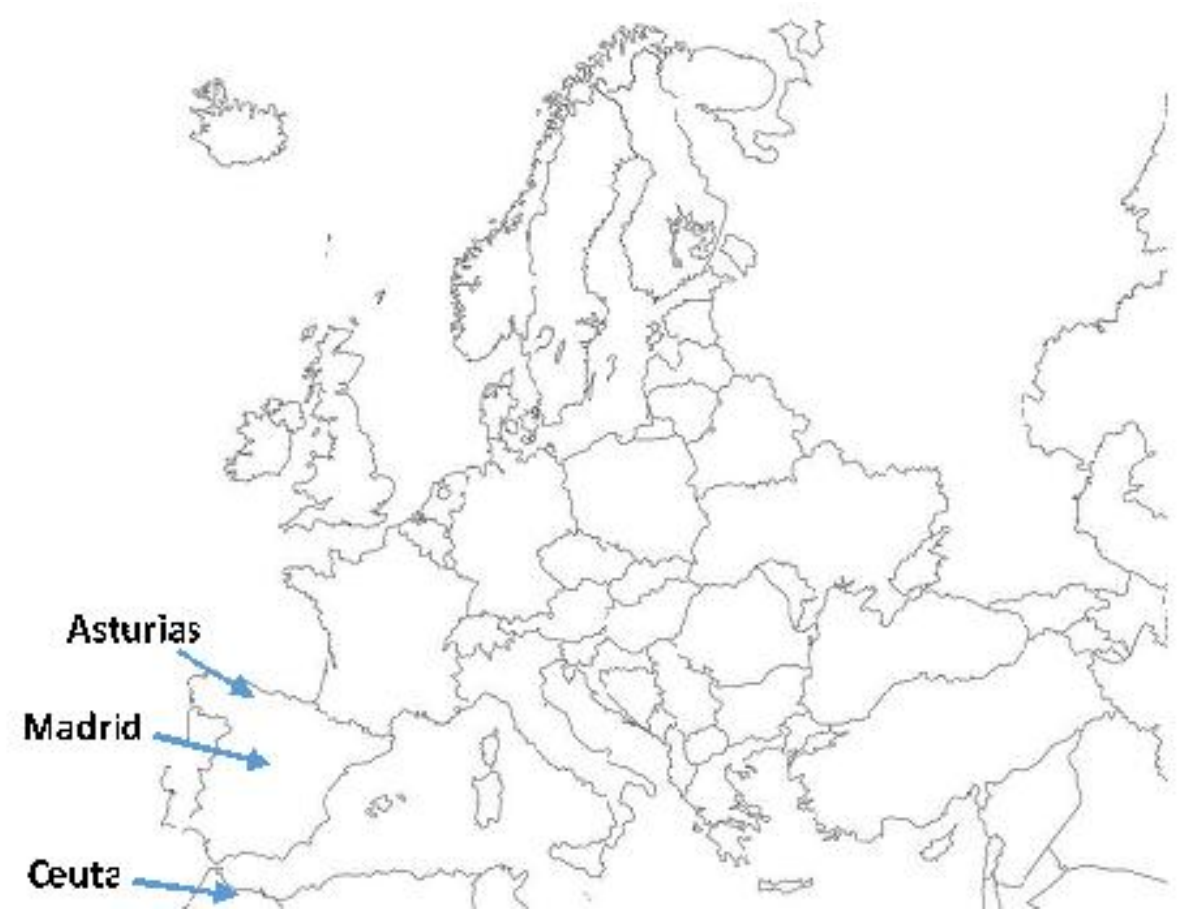

Figure 1. Location of the secondary schools involved in this study

A total of 34 teachers were involved in the methodological change and 372 students experienced this didactic innovation (Table 1) while enrolled in subjects such as language, mathematics, fine arts, physical education, social studies, science, music, philosophy, French, English, technology, economics, physics and chemistry or classical culture.

Table 1. Study sample

\begin{tabular}{|l|c|c|c|c|}
\hline Schools & IES María Guerrero & IES Clara Campoamor & IES Pando & Total \\
\hline Teachers & 14 & 9 & 11 & 34 \\
\hline Students & 117 & 132 & 123 & 372 \\
\hline
\end{tabular}

To know the opinion of teachers on teaching skills needed to develop PBL methods in the classroom, we developed an ex-post facto correlational design (Cohen et al. 2011) that involved all of the teachers (26 females and 8 males), with an average of 13.74 years of teaching experience $(\sigma=8,15)$. An ad-hoc questionnaire with personal and professional variables (to rate from min. 1 to max. 5) (Flick, 2009) was designed to assess the beliefs and attitudes of teachers on the PBL teaching method (Table 2). 
Table 2. Questionnaire for teachers

\begin{tabular}{|c|c|c|c|c|c|c|c|c|c|c|}
\hline \multicolumn{5}{|c|}{ Important for me personally } & TEACHING STAFF & \multicolumn{5}{|c|}{$\begin{array}{c}\text { Important for teaching and } \\
\text { learning }\end{array}$} \\
\hline $\begin{array}{c}\text { It's not } \\
\text { important }\end{array}$ & 2 & 3 & 4 & $\begin{array}{c}\text { It's very } \\
\text { important }\end{array}$ & & $\begin{array}{c}\text { It's not } \\
\text { important }\end{array}$ & 2 & 3 & 4 & $\begin{array}{l}\text { It's very } \\
\text { important }\end{array}$ \\
\hline & & & & & $\begin{array}{l}\text { Follow the curriculum and the } \\
\text { methodology that is already established }\end{array}$ & & & & & \\
\hline & & & & & Introduce changes in methodology & & & & & \\
\hline & & & & & $\begin{array}{l}\text { Explain the subject and propose } \\
\text { homework }\end{array}$ & & & & & \\
\hline & & & & & $\begin{array}{l}\text { Create cooperative groups with students } \\
\text { to work on topics related to the subject }\end{array}$ & & & & & \\
\hline & & & & & Work in interdisciplinary teams & & & & & \\
\hline & & & & & $\begin{array}{l}\text { Develop the teaching method with which } \\
\text { I feel more comfortable }\end{array}$ & & & & & \\
\hline
\end{tabular}

We also wanted to know the views of the secondary education students facing PBL methods. The average age of the students was 14.14 years old $(\sigma=1.70)$. A specific 7 items questionnaire (min. 1 max. 5) was designed to assess the competencies related to PBL that students considered necessary to develop their learning, distinguishing between those they considered important personally and those they thought were important for their learning (Table 3).

Table 3. Questionnaire for students

\begin{tabular}{|c|c|c|c|c|c|c|c|c|c|c|}
\hline \multicolumn{5}{|c|}{$\begin{array}{l}\text { Important for me } \\
\text { personally }\end{array}$} & STUDENT BODY & \multicolumn{5}{|c|}{ Important for my learning } \\
\hline $\begin{array}{c}\text { It's not } \\
\text { important }\end{array}$ & 2 & 3 & 4 & $\begin{array}{c}\text { It's very } \\
\text { important }\end{array}$ & & $\begin{array}{c}\text { It's not } \\
\text { important }\end{array}$ & 2 & 3 & 4 & $\begin{array}{l}\text { It's very } \\
\text { important }\end{array}$ \\
\hline & & & & & $\begin{array}{l}\text { I prefer a curriculum in which I can } \\
\text { actively participate }\end{array}$ & & & & & \\
\hline & & & & & $\begin{array}{l}\text { I prefer a curriculum in which the issues } \\
\text { are well explained and later could do } \\
\text { exercises }\end{array}$ & & & & & \\
\hline & & & & & $\begin{array}{l}\text { I understand better the contents when } \\
\text { developed in individual practical tasks or } \\
\text { projects }\end{array}$ & & & & & \\
\hline & & & & & $\begin{array}{l}\text { I understand better the contents when } \\
\text { developed in group practical task or } \\
\text { projects }\end{array}$ & & & & & \\
\hline & & & & & $\begin{array}{l}\text { I show better what I have learned through } \\
\text { final exams }\end{array}$ & & & & & \\
\hline & & & & & $\begin{array}{l}\text { I show better what I have learned through } \\
\text { continuous assessment tasks }\end{array}$ & & & & & \\
\hline & & & & & $\begin{array}{l}\text { I complete the knowledge acquired in } \\
\text { class with information I seek personally }\end{array}$ & & & & & \\
\hline
\end{tabular}




\section{Macrothink}

\section{Results}

The beliefs and attitudes of the 34 teachers involved in the PBL teaching method showed (Figure 2) statistically significant correlations $(\mathrm{p} \leq .001)$ between personal and professional variables (Pearson's $r>.70$ ), predicting in a statistically significant way the total of personal variables above the professionals $\mathrm{F}(1,31)=144.29 ; \mathrm{p} \leq .001 ; \mathrm{R}$-squared $=.828$.

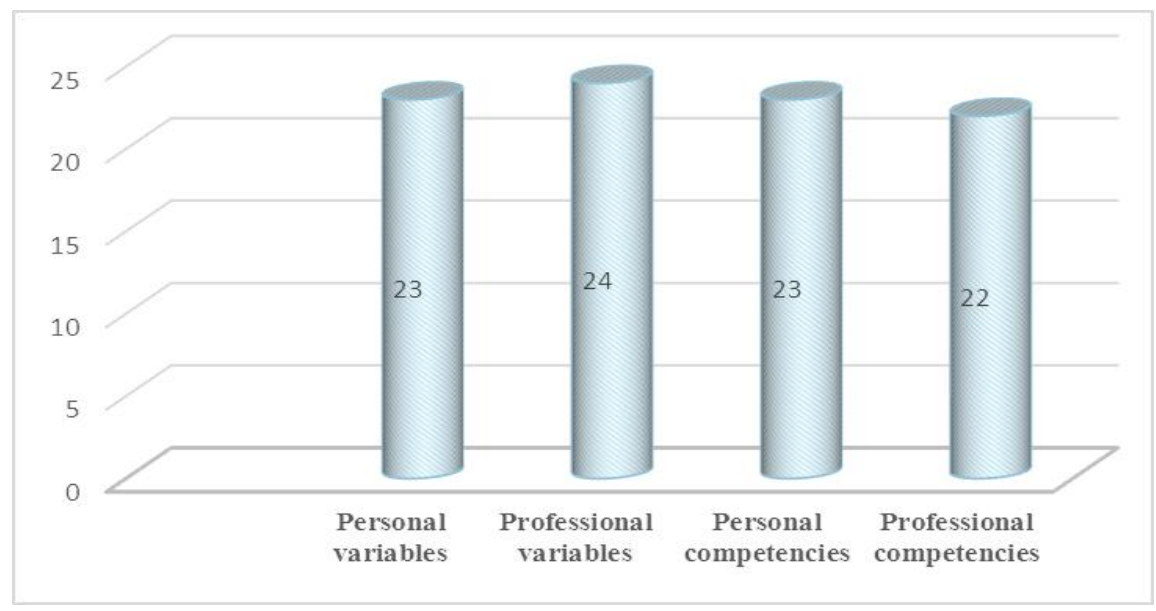

Figure 2. Beliefs and attitudes of teachers on the PBL teaching method

The data obtained show that there are no statistically significant differences between the total perception of the teachers on their personal $(\mathrm{M}=23.42 ; \sigma=3.03)$ and professional competencies $(\mathrm{M}=23.21 ; \sigma=3.23)$.

Students (Figure 3) value continuous evaluation more positively (97\%) than final exams (91\%). They prefer group activities (97\%) to individual activities (92\%), although these differences are reduced when it comes to explaining the level of personal involvement in participative (94\%) or traditional classes $(94.6 \%)$. We find statistically significant correlations $(\mathrm{p} \leq .001)$ between personal variables and those that concern the requirements of learning (Pearson's $r>.70$ ).

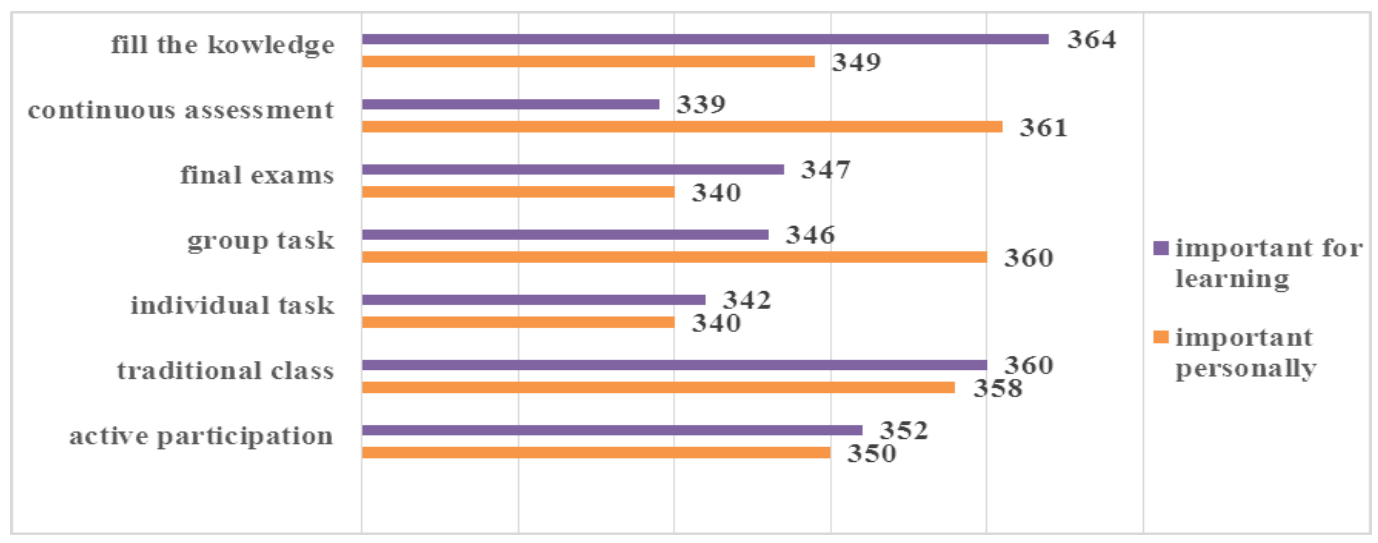

Figure 3: Secondary education students before PBL methods 
We appreciate significant differences in the total of variables important for the learning $(\mathrm{M}=26.76, \sigma=4.11)$ and those considered to be important personally $(\mathrm{M}=24.33, \sigma=4.35)$; Student's $t(372)=-11.958 ; \mathrm{p} \leq .001)$. To complement the learning acquired in classroom is considered more important for learning (97\%) than personally (93\%).

\section{Conclusions and Discussion}

In view of the questionnaire, results on the beliefs and attitudes of teachers on the PBL teaching method, our study shows that there are no differences between personal and professional competencies that the teachers consider necessary for the development of the PBL methodology. The problem seems to be located in the workload that it represents to adopt a different approach to the usual expository method or to move away from acquired routines. Teachers find it hard to change their teaching ways (Stivers and Cramer, 2009), and we have seen it here when a new teaching method is introduced in the classroom. The schools under study are big. The IES María Guerrero in Madrid has nearly 2,000 students and only 35 teachers were involved in this initiative. The IES Clara Campoamor in Ceuta has about 700 students and only 20 teachers took part in the methodological change. The IES Pando in Asturias also has almost 700 students and only 27 teachers thought it was a good idea to do something different in the dynamics of the classes. Nevertheless, initiatives like this one break the status quo of teaching routines and teach teachers to work in cooperative teams and encourage these dynamics of work among their students. Furthermore, by establishing a professional and personal contact between educational centers, teachers build educational networks that aid to improve their instructional practices (James and McCormick, 2009).

In the case of the results of the questionnaire done for secondary education students who were going to experience the PBL method, our study highlights that while students are inclined to work with active methods in class, they do not consider it so important for their personal development. It also shows that they are comfortable in a passive and traditional learning. This may respond to force of habit, since they have only experienced the old models of instruction, with the teacher exposing the knowledge students need to memorize to then to demonstrate the strength of their memory in a traditional assessment (Wisniewski, 2010). It is the same way of teaching and learning that their parents or their grandparents experienced, and they think that is how it should be. This is why teachers who have carried out this methodological change initiative propose to promote active methodologies in the 21 st century classroom.

The main conclusions of this study show that the main problem in developing a PBL methodology, for teachers, is the effort it takes to adopt a different approach to the usual expository method or to move away from the routines acquired in teaching. The main problem on the student's side is that although students are inclined to work in active methodologies they are comfortable in a passive and traditional learning.

This initial assessment in the sphere of project-based learning and cooperative learning among teachers and students allows us a broad view of the scope of our initiative. The next steps we intend to take will be an assessment in the middle of the process and a global assessment on having finished the academic year to test the strengths and weaknesses of the 
introduced changes. Our aim is to change the roles in the classroom and to show students and teachers that we can all work and share the spaces of knowledge within our reach.

\section{References}

Bergold, J., \& Thomas, S. (2012). Participatory Research Methods: A Methodological Approach in Motion. Forum: Qualitative Social Research, 13(1). Retrieved from http://www.qualitative-research.net/index.php/fqs/article/view/1801/3334

Canaleta, X., David Vernet, D., Vicent, L., \& Montero, J. A. (2014). Master in Teacher Training: A real implementation of Active Learning. Computers in Human Behavior, 31, 651-658. https://doi.org/10.1016/j.chb.2013.09.020

Clifford, P., Friesen, P., \& Lock, J. (2004). Coming to teaching in the 21st century: A research study conducted by the Galileo Educational Network. Retrieved from http://www.galileo.org/research/publications/ctt.pdf

Cohen, L., Manion, L., \& Morrison, K. (2011). Research Methods in Education (7th ed.). New York: Routledge.

Deslauriers, L., Schelew, E., \& Wieman, C. (2011). Improved learning in a large-enrollment physics class. Science, 332, 862-864. https://doi.org/10.1126/science.1201783

Efstratia, D. (2014). Experiential education through project based learning. Procedia - Social and Behavioral Sciences, 152(7), 1256-1260. https://doi.org/10.1016/j.sbspro.2014.09.362

Emo, W. (2015). Teachers' Motivations for Initiating Innovations. Journal of Educational Change, 16(2), 171-195. https://doi.org/10.1007/s10833-015-9243-7

English, M. C., \& Kitsantas, A. (2013). Supporting Student Self-Regulated Learning in Problem-and Project-Based Learning. Interdisciplinary Journal of Problem-based Learning, 7(2), 128-150. http://dx.doi.org/10.7771/1541-5015.1339

European Commission. (2013). Supporting teacher competence development for better learning outcomes. Retrieved from http://ec.europa.eu/education/policy/school/doc/teachercomp_en.pdf

Eurostat. (2014). Europe 2020 indicators - education. Retrieved from http://ec.europa.eu/eurostat/statistics-explained/index.php/Europe_2020_indicators_-_educati on

Flick, U. (2009). An introduction to qualitative research (7th ed.). London: Sage.

Gillies, R. M., \& Boyle, M. (2010). Teachers' reflections on cooperative learning: Issues of implementation. Teaching and Teacher Education, 26(4), 933-940. https://doi.org/10.1016/j.tate.2009.10.034

Holmes, K., Clement, J., \& Albright, J. (2013). The complex task of leading educational change in schools. School Leadership \& Management, 33(3), 270-283. https://doi.org/10.1080/13632434.2013.800477 
James, M., \& McCormick, R. (2009). Teachers learning how to learn. Teaching and Teacher Education, 25(7), 973-982. https://doi.org/10.1016/j.tate.2009.02.023

Kärkkäinen, K. (2012). Bringing About Curriculum Innovations. Implicit Approaches in the OECD Area. OECD Education Working Papers, 82. https://doi.org/10.1787/5k95qw8xzl8s-en

Kirby, J. R., \& Lawson, M. J. (Ed). 2012). Enhancing the quality of learning. Dispositions, Instruction, and Learning processes. New York: Cambridge University Press.

Klug, J., Krause, N., Schober, B., Finsterwald, M., \& Spiel, C. (2014). How do teachers promote their students' lifelong learning in class? Development and first application of the LLL Interview. Teaching and Teacher Education, 37, 119-129. https://doi.org/10.1016/j.tate.2013.09.004

Murphy, M., Redding, S., \& Twyman, J. (Ed.) (2013). Handbook on Innovations in Learning. Temple University, Philadelphia: Center on Innovations in Learning.

Pevida, D., \& Gallego, A. (2013). Compartir para aprender y aprender a cooperar. Oviedo: Consejería de Educación, Cultura y Deporte. Retrieved from http://web.educastur.princast.es/cpr/oviedo/web/index.php?option=com_recursos\&task=ficha \&id_recurso=49\&id_asesoria=\&Itemid=19

Stivers, J., \& Cramer, S. F. (2009). A Teacher's Guide to Change: Understanding, Navigating, and Leading the Process. California: Corwin, Sage.

Terhart, E. (2013). Teacher resistance against school reform: Reflecting an inconvenient truth. School Leadership \& Management, 33(5), 486-500. https://doi.org/10.1080/13632434.2013.793494

Teúileanu A. (2014). Challenges to meaningful learning in social studies - the key competences as an opportunity to students' active participation. Procedia - Social and Behavioral Sciences, 128, 192-197. https://doi.org/10.1016/j.sbspro.2014.03.142

Trujillo, F. (2012). Propuestas para una escuela en el siglo XXI. [Proposals for a school in the XXI century]. Madrid: Libros de la Catarata.

Wisniewski, M. A. (2010). Leadership and the Millennials: Transferring today's technological teens into tomorrow's leaders. Journal of Leadership Education, 9(1), 53-68. https://doi.org/10.12806/V9/I1/RF4

\section{Copyright Disclaimer}

Copyright for this article is retained by the author(s), with first publication rights granted to the journal.

This is an open-access article distributed under the terms and conditions of the Creative Commons Attribution license (http://creativecommons.org/licenses/by/3.0/). 